This is an Author's Accepted Manuscript of an article published in Article title:

From Governing to Managing: Exploring Modes of Control in Private Equity Relationships

Authors: Ditillo, Angelo

Journal The European Accounting Review

Pagination 06 Jan 2021

Online publication date 06 Jan 2021

Copyright is held by Taylor and Francis. 


\title{
From Governing to Managing: Exploring Modes of Control in Private Equity Relationships
}

\begin{abstract}
Despite the economic significance of private equity (PE) firms, there has been limited investigation into the control mechanisms they implement to manage relationships with their portfolio companies. Through a comparative field study, we describe the role and characteristics of controls implemented by PE firms and the contextual factors associated with the relative importance of different control mechanisms. Evidence shows that control mechanisms play an important role in directing the actions of portfolio companies and that there is significant variation between PE firms in terms of the combination of formal contracting, results, behaviour, and social controls that are relied upon. We find that the primary factors associated with the choice of control combination are the equity arrangement and the perceived cognitive style of top management in the portfolio company. From our analysis, we derive a framework of four control combinations that are aligned to variations in these two factors. Our analysis also points to the potential interdependencies that arise between control mechanisms within each control combination.
\end{abstract}




\section{From Governing to Managing: Exploring Modes of Control in Private Equity Relationships}

\section{Introduction}

A small but growing body of literature investigates the association between ownership and management accounting and control (MAC) mechanisms. Researchers have considered, for example, the role of family ownership (e.g. Jakobsen, 2017; Speckbacher \& Wentges, 2012), venture capitalist investment (e.g. Christner \& Stromsten, 2015; Davila \& Foster, 2005; Granlund \& Taipaleenmäki, 2005), and ownership in professional services firms (e.g. King \& Clarkson, 2015), in explaining the adoption and effectiveness of control mechanisms. One type of ownership arrangement that has largely escaped attention by MAC researchers is private equity (PE) (see however Nama \& Lowe, 2014). This is somewhat surprising given the economic significance of PE investment - fundraising by US PE firms grew by more than 100 times between 1985 and 2006 (Bloom et al., 2015) and by 2018 PE assets under management reached nearly \$5.8tn worldwide (McKinsey, 2019). PE investments are also shown to have similar returns to share market indices, even after accounting for often significant management fees (Moskowitz \& Vissing-Jørgensen, 2002; Kaplan \& Schoar, 2005). Moreover, there are persistence in returns - PE firms whose funds outperform the industry in one fund will tend to do so with subsequent funds - suggesting that these PE firms may implement certain processes or mechanisms that contribute to maximizing portfolio company performance (Kaplan \& Schoar, 2005).

One possible reason for the lack of attention by MAC researchers is the prevailing view that PE relationships have implications primarily for the choice of financial and governance structures (Bloom et al., 2015; Gompers et al., 2016). Typically adopting an agency perspective, research in the fields of economics and finance focus on the financial contracts 
and corporate governance structures associated with PE ownership (i.e. increased leverage, concentrated ownership, managerial equity ownership, and board participation) which are argued to reduce agency costs and increase the exit value of PE investments (Kaplan \& Strömberg, 2009; Wright et al., 2009). However, it has been acknowledged that many monitoring and control activities of PE firms are 'largely non-contractible, yet may have real consequences' (Bottazzi et al., 2008, p. 489), suggesting that a much wider range of mechanisms are likely to contribute to the success of PE investments.

Recent MAC research has also shifted attention from individual mechanisms to how controls operate in combination (Grabner \& Moers, 2013). While this stream of research is only just emerging, recent studies reveal that the different ways that MAC mechanisms combine as a package are shaped by the contextual conditions of the organization (Bedford \& Malmi, 2015; Bedford, Malmi \& Sandelin, 2016). In this study, we adopt the package perspective to investigate the control mechanisms that PE firms employ to manage the portfolio companies they invest in. We also explore the factors that are associated with the different combinations or packages that PE firms implement.

To examine these issues, we conducted a comparative field study of six PE firms in one continental European country (i.e. Italy). We chose this setting to focus our study on PE investment into private small-to-medium enterprises and family owned firms. ${ }^{1}$ Primary concerns in these firms centre upon entrepreneurship, managerial succession, and market expansion (Fenn et al., 1997; Wright et al., 2009). This significantly reduces the scope for governance structures to add value through the reduction of agency costs, and instead shifts

\footnotetext{
${ }^{1}$ Most PE research focuses on leveraged buyouts of publicly listed firms in the US and UK markets. While these deals are typically the largest in value, Strömberg (2007) reports that in the period from 1970 to 2007, public-toprivate buyouts accounted for less than 10\% of total PE transactions and less than $30 \%$ of total transaction value, and this is even more pronounced in continental Europe.
} 
attention to the mechanisms and processes used to actively monitor and direct the actions of managers in the invested firms. Our empirical evidence reveals that PE firms implement a wide range of mechanisms to provide strategic advice and guidance to managers of their portfolio companies as well as to monitor and control their activities. We also find that there are two main factors, equity arrangement and perceived cognitive style, that are particularly influential in shaping the choice of control combinations implemented by PE firms.

Our study contributes to the literature in two main ways. First, we describe the role and characteristics of the control mechanisms commonly adopted by PE firms to manage their portfolio firms. Consistent with prior literature, we find that contractual agreements and formal governance mechanisms (e.g. board participation, managerial equity ownership) are relatively standard components of the package of controls employed by PE firms (Wright et al. 2009). However, a wider range of formal and informal control mechanisms - joint planning and goal setting, policies and procedures, performance monitoring, partner selection, and personal interaction - were frequently found to be central to efforts to monitor and control the activities of portfolio companies. We also highlight the importance of social control as central to control efforts in many PE relationships.

Second, we provide evidence on the factors that explain variation in the combination of controls employed by PE firms. While a number of factors emerge from our analysis, there are two particularly influential factors that appear to shape structure of the control package - (1) the equity arrangement of the PE firm (i.e., whether they hold a majority or minority ownership position), and (2) the perceived cognitive style of the portfolio firm top manager(s) (i.e., entrepreneurial or managerial cognition). Based on these factors we develop a framework for understanding control combinations in PE relationships. Our analysis also points to the 
potential interdependencies between control mechanisms unique to each control combination (Bedford, 2020; Grabner \& Moers, 2013).

The remainder of our study is organized as follows. The next section defines PE and reviews the literature on how PE firms control their portfolio companies, as well as the contextual factors that might be associated with different control choices. The research method is then described, before presenting the findings that emerge from the field study analyses. The subsequent section outlines a framework to explain how different control combinations are aligned to variations in equity arrangement and the perceived cognitive style of portfolio company top management. Conclusions, limitations, and suggestions for future research are presented in the final section.

\section{Literature Review}

$\mathrm{PE}$ is a form of financial intermediation in which a PE firm raises capital from institutional and individual investors to make direct equity investments in a portfolio of private organizations. ${ }^{2}$ The PE fund is typically organised as a limited partnership (Kaplan \& Schoar, 2005). The capital providers serve as limited partners, while the PE firm acts as the general partner and is responsible for investment decisions. PE funds usually have an agreed upon timeframe in which the PE firm must invest the capital and provide a return to the limited partners.

PE is distinct from most other forms of financial intermediation in at least three respects. First, compared to blockholders of publicly listed firms (i.e., shareholders that hold a large proportion

\footnotetext{
${ }^{2}$ The focus of our literature review is on PE and control arrangements in this setting. We mention studies regarding the association between ownership and control where relevant, but a more comprehensive outline of this literature is beyond the scope of this study.
} 
of ownership), PE firms invest in privately held organisations (Metrick \& Yasuda, 2011). ${ }^{3}$ Second, unlike mutual funds and hedge funds, PE funds are closed-end investments with capital locked-in for the life of the fund, typically between seven to ten years (Kaplan \& Strömberg, 2009). During this period the PE firm uses fund capital along with debt financing to take large, often controlling, equity positions in private firms. Third, in contrast to the typical investor in public companies, the significant ownership stakes of PE firms enable them to 'actively influence actions of the management of the companies they invest in' (Metrick \& Yasuda, 2011, p. 623). ${ }^{4}$

Research examining control by PE firms is predominantly informed by agency theory. This literature considers PE as an alternate governance structure to public ownership, and examines its relative effectiveness at alleviating costs that arise from information asymmetry and divergent interests between the principal (owners) and the agent (managers). The central proposition is that PE governance structures are superior to those of public organizations as they provide more powerful incentives for managers to take actions that are aligned with the interests of owners. Governance structures in firms with PE ownership typically entail increased levels of managerial equity ownership and performance-based compensation, highly leveraged capital structures, and enhanced monitoring through board participation and timely access to information (Bernstein et al., 2017; Kaplan \& Strömberg, 2009). The combination of equity ownership and tighter monitoring reduces information asymmetry and incentives for

\footnotetext{
${ }^{3}$ Transactions may involve either firms that are privately owned (private-to-private) or publicly-owned, in which case the PE firm undertakes a buyout of existing shareholders to take the firm private (public-to-private).

${ }^{4} \mathrm{PE}$ firms can also be differentiated from angel investors and venture capitalists. Angel investors are typically individual investors who use their own money to fund small startups or entrepreneurial ventures, whereas PE firms use investor's capital to make investments in a portfolio of companies (Metrick \& Yasuda, 2011). Venture capitalists are often considered as a subset of PE, however, they can be distinguished by their focus on early-stage or emerging firms, with higher growth and associated risk, and typically do not take majority control (Kaplan \& Strömberg, 2009).
} 
managerial opportunism (Baker \& Wruck, 1989), while debt obligations imposed by high leverage minimises concerns over the allocation of free cash flow (Jensen, 1989).

Despite significant attention towards PE governance and its consequences, the existing literature provides an incomplete picture of control arrangements implemented by PE firms. First, the majority of studies examine buyouts of publicly listed firms (public-to-private transactions), with relatively little attention given to other forms of acquisition (Metrick \& Yasuda, 2011 $)^{5}$. In private-to-private transactions, agency theory is likely to provide only partial explanations for performance outcomes and choice of control mechanisms, as ownership is often already highly concentrated prior to the transaction. Second, while prior research considers the relative effectiveness of PE as a governance structure, examination of the actual practices and mechanisms within these structures has been largely ignored. As a result, we know little about what control mechanisms are employed within, and how they vary across, PE relationships. Moreover, the few studies that do report on the actual mechanisms associated with PE governance (e.g. Baker \& Wruck, 1989) are mostly limited to formal contracting in public firm buyouts, with little examination of the role of other control mechanisms.

\subsection{Control Mechanisms in PE relationships}

Control in PE relationships refers to the ability of the PE firm to monitor and direct the behaviour of portfolio company management during the post-investment period. As most prior research has been conducted from an agency perspective, the concern has largely been centred upon understanding how control is achieved through formal contracting. Formal contracts

\footnotetext{
${ }^{5}$ One of the only studies investigating management control in this context is that by Bruining, Bonnet, and Wright (2004). Drawing on the framework of Simons (1995), they examine how management controls are implicated in the formulation and implementation of strategy in a case study of two firms that went through a management buyout.
} 
represent binding legal agreements that detail the rights and obligations of parties throughout the course of a relationship (Poppo \& Zenger, 2002). Contracts vary in complexity with more complex contracts containing greater precision and detail (Carson et al., 2006; Poppo \& Zenger, 2002). Contracts commonly specify the roles and responsibilities of each party, monitoring procedures, performance expectations, and the potential sanctions for noncompliance. Particularly important in PE relationships are the allocation of contractual rights that enable direct intervention in the operations of an invested firm, such as veto rights over major strategic decisions, access to additional capital, changes to managerial personnel, and determining compensation structures (Fenn et al., 1997; Metrick \& Yasuda, 2011).

Specifically, PE contracts typically include the allocation of three classes of rights (Kaplan \& Strömberg, 2003). The first are cash flow rights, which refer to the redistribution of cash flow from the company to its investors. Cash flow rights can be made contingent on certain performance measures ('performance vesting') or on the occurrence of certain events ('time vesting'). The second are control rights, which concern the voting rights and board seats, that provide power over corporate decisions. Control rights are granted to shareholders depending on the kind of securities they hold and the agreed upon contractual specifications. The allocation of control rights are often made contingent upon publicly verifiable 'signals' that are correlated with the state of the firm (Aghion \& Bolton, 1992), such as financial or non-financial performance measures (Kaplan \& Strömberg, 2001). When the portfolio company performs poorly on these observable measures the PE firm gains greater control (Kaplan \& Strömberg, 2003). Third, liquidation rights relate to the possibility of triggering default of the company in order to force liquidation and obtain payments that are owed to the providers of financial resources. Liquidation rights differ depending on the level of seniority of the claims held by capital providers. Additional contractual specifications include non-compete clauses (if the 
entrepreneur leaves the firm) and exit rights (e.g. to determine the method of exiting the investment) (Bienz \& Uwe, 2010).

Although there is little direct empirical evidence, it is generally acknowledged that PE firms activate a far broader combination of control mechanisms that extend beyond ex-ante contractual specifications (Fenn et al., 1997; Nama \& Lowe, 2014). ${ }^{6}$ A common distinction in MAC literature is between results, behaviour, and social controls (Dekker, 2004; Merchant \& Van der Stede, 2017). Results controls focus on the achievement of predetermined objectives and involve the specification of performance targets, monitoring of variances, and the use of incentives. In particular, incentives are regarded as one of the primary mechanisms for PE firms to control the behaviour of invested companies (Fenn et al., 1997). Performance targets typically relate to cash flow and long-term value (Baker \& Wruck, 1989; Wruck, 2008). Common incentive mechanisms include managerial equity ownership and 'earn-out' bonuses, in which managers receive increased ownership by meeting performance objectives over time (Jensen, 1989; Kaplan \& Stromberg, 2009). These may also take the form of exit bonuses based on a predetermined metric (e.g. exit value, investment multiple). Periodic reporting of accounting and other measures of performance is likely to be required, while more active PE firms might be involved in target setting and financial forecasting (Beuselinck et al., 2008; Kaplan \& Stromberg, 2004). A recent study by Bloom et al. (2015) shows that PE-owned firms more frequently adopt merit-based compensation policies with difficult targets tied to both short and long term firm performance, relative to firms with other ownership structures (e.g. government, private, and family ownership).

\footnotetext{
${ }^{6}$ Nama and Lowe (2014) is the only study we are aware of that examines the role of accounting mechanisms in PE firms. They focus on how accounting is intertwined with PE activities across the different parts of a PE value chain. However, only limited insight is provided into the role of accounting as a control mechanism for influencing managerial behaviours in invested firms.
} 
Behaviour controls regulate firm activities by specifying how tasks are to be performed or through placing constraints on the behaviours of invested firm managers, including planning processes, codified rules and operating procedures, authority structures, and approval procedures (Dekker, 2004; Merchant \& Van der Stede, 2017). While there are few first-hand accounts of the types of behaviour controls implemented by PE firms, some insights are provided by the venture capital literature (Denis, 2004; Metrick \& Yasuda, 2011). Research shows that venture capitalists are active participants on boards of directors, with significant influence over the financial and strategic decisions of the firm (Bruining \& Wright, 2002). Other studies find that lead venture capitalists are often involved in developing and reviewing strategic plans (Kaplan \& Strömberg, 2000), and undertake site visits more than once a month to enhance monitoring and oversight of the firm (Gorman \& Sahlman, 1989; Lerner, 1995).

Social controls foster socialization and interaction between firms to enable control through the implicit understandings, social norms, and mutual trust (Dekker, 2004; Hoetker \& Mellewigt, 2009; Ouchi, 1979). Social control mechanisms can include direct contact through site visits, information exchange through meetings and informal contacts, and shared decision making (Dekker, 2004; Fenn et al., 1997). Through repeated exchanges the PE firm and investee managers develop personal ties and an understanding about the expectations of the other party (Uzzi, 1997). These interactions build shared norms and enhance trust, which facilitates adaptation to unforeseen events, commitment to common interests, and problem solving through the sharing of private information. Another mechanism for developing trust is personnel selection (Merchant \& Van der Stede, 2017; Dekker, 2008). This can occur during investment selection or post-acquisition. PE firms go through rigorous processes to identify investment targets. During this process they acquire information about the capabilities and reputation of key managers, especially when acquisition is private rather than by means of an 
auction (Fenn et al., 1997). If trust is developed between parties prior to investment, this allows written contracts to be left incomplete without concerns of opportunistic behaviours (Carson et al., 2006). Post-acquisition PE firms often have control rights over the hiring and firing of key personnel. The potential importance of personnel selection for effective control is suggested by Acharya and Kehoe (2008) who find that in nearly seventy percent of PE transactions the CEO is replaced at some point during the life of the investment, and more than a third of replacements occur within the first 100 days.

A potential impediment to social control is that investor and investee managers often have only limited contact prior to the transaction. This suggests that social control is unlikely to act as a complete substitute to formal contracting. However, some field study evidence indicates that even if complex formal contracts are constructed, they can have limited importance for ex-post control. In an investigation of venture capital investments Graebner and Eisenhardt (2004) find that control is rarely exercised through 'monitoring and ratification of specific choices' but is directed through 'broader issues of strategic advice and connections' (p. 398) and an emphasis on 'social exchange, interdependence and cooperation' (p. 400). For instance, they report that investors and managers almost never resort to contractual rights (e.g. board votes) to resolve conflicts but seek mutually acceptable outcomes irrespective of who has formal control of the firm.

An additional consideration is how different control mechanisms are combined. Recent studies have begun to reveal how control and governance mechanisms are combined in different ways and the contexts in which those bundles or packages operate (Aguilera et al., 2008; Bedford \& Malmi, 2015; Kruis et al., 2016). There is also increasing evidence that control mechanisms interact to mutually influence performance outcomes, through either complementary or 
substitutional effects on one another (Bedford, 2020; Grabner \& Moers, 2013). We take these considerations into account in posing the following research question:

RQ1: What control mechanisms do PE firms employ to manage their portfolio companies and how are they combined?

\subsection{Factors Associated with PE Control Mechanisms}

No prior research has specifically investigated reasons for variations in the choice and relative importance of control mechanisms implemented in PE relationships. However, a few studies in the financial contracting and corporate governance literatures point to organisational and contextual attributes that might be associated with this variation. Bacon et al. (2012) show that the anticipated amount of time remaining until the PE firm exits the investment is associated with the use of certain human resource management practices. They report that the longer the time to exit, the more likely the invested firm will implement high performance work practices (e.g., training, job flexibility, internal promotions, performance-based pay). They also find that the type of investment strategy is an important consideration, with PE firms following a 'buyand-build' strategy more likely to be associated with the adoption of high performance work practices in their portfolio firms than those following a 'cost-reduction' approach.

Kaplan and Strömberg $(2003,2004)$ investigate variations in contractual arrangements between venture capitalists (VCs) and entrepreneurs. Their research indicates that the prior history of the entrepreneur, relationship duration, industry characteristics, and degree of reliance on human capital, influences the formal contractual specifications implemented. Consistent with agency theory, they find that the pay to performance sensitivity of the entrepreneur's compensation is associated with the perceived level of risk; for instance, entrepreneurs with previously successful ventures had less performance sensitive incentives, while performance 
sensitivity declines the longer the duration of the relationship, consistent with the expectation that the level of information asymmetry will decrease over time. Industry characteristics are also significant determinants — in industries where explicit performance standards are relatively noisy (i.e., in high industry volatility, high $\mathrm{R} \& \mathrm{D}$, emerging sectors), VCs rely more on time vesting (compensation dependent on time spent with the firm) than performancedependent incentives.

Literature on contracting and corporate governance suggests that the equity arrangement will be an important consideration for how the relationship between a PE firm and a portfolio company is managed (Daily et al., 2003). ${ }^{7}$ The main consideration is whether or not the PE firm has a controlling interest in the portfolio company. Although majority ownership has the benefit of conferring residual control rights to the PE firm (Grossman \& Hart, 1986), formal contracts and control mechanisms are likely to play a significant role. Although in PE relationships the entities remain separate (Lehn \& Poulsen, 1989), control arrangements may mirror how a parent company controls a subsidiary (Baliga \& Jaeger, 1984; Goold et al., 1994). Common control mechanisms in these arrangements include well-defined authority structures, detailed planning and approval processes, and formal mechanisms for dispute resolution (Gulati \& Singh, 1998). Results controls, such as budgeting processes and incentive structures, are particularly important, providing direct mechanisms to clarify and motivate desired performance (Goold et al., 1994). In non-controlling interests, the PE firm does not have the benefit of residual control rights. Additionally, they will tend to have a more limited capacity to implement formal control mechanisms implying that social controls are likely to be relied upon to a greater extent (Gulati \& Singh, 1998).

\footnotetext{
${ }^{7}$ There is also some research investigating the role of venture capital on the adoption of MAC practices. This research shows that venture capital is associated with a greater use of formal controls, such as budgets, performance-based pay, and approval procedures (Davila \& Foster, 2005).
} 
Finally, Wright et al. (2000) highlight the role of individual cognition in developing a model to explain the performance potential of privatization buyouts. They distinguish between two cognitive styles - entrepreneurial and managerial. ${ }^{8}$ Entrepreneurial cognition refers to the extensive use of heuristics and intuition in decision making and a preference for relational and experiential learning, while managerial cognition relates to an inclination for more systematic and structured decision making and a greater tendency towards compliance (Wright et al., 2000). These distinctions are supported by research demonstrating that entrepreneurs and nonentrepreneurs consistently display different modes of thinking and preferences (Baron, 1998; Busenitz \& Barney, 1997; Mitchell et al., 2007). This research suggests that individuals with an entrepreneurial mindset are likely to ignore formalized controls, and in some instance these controls may event generate conflict and resentment towards interventions by the PE firm (Allinson \& Hayes, 1996; Mitchell et al., 2007). In contrast, individuals with managerial cognitions are more accustomed to being guided by formal policies and procedures and to using quantified information to justify decisions. As such, PE firms are better able to leverage formal control mechanisms to influence these managers (Wright et al., 2000).

These studies suggest a range of factors that may be relevant to understanding variation in control practices in PE relationships. In particular, the literature points to ownership stake and individual cognition as being potentially important in this respect, as well as time to exit, investment strategy, industry characteristics, prior performance, and relationship duration. However, given that there is no direct evidence on factors relating to PE relationships

\footnotetext{
${ }^{8}$ Cognitive style refers to an individual's preferred and habitual process for 'acquiring, processing, maintaining, and using knowledge for problem solving' (Miron-Spektor et al., 2011, p. 741).
} 
specifically, we leave open the possibility that there are other significant factors associated with variation in control choices. Our second research question is stated as follows:

RQ2: What factors are associated with different control combinations employed by PE firms to manage their portfolio companies?

\section{Research Setting and Methods}

\subsection{Selection of PE Firms and Their Characteristics}

Our study was conducted through an embedded comparative field study with literal and theoretical replications (Scapens, 1990; Ryan, Scapens, \& Theobald, 2002; Yin, 2009)9. The unit of analysis was the control arrangement implemented by the PE firm to manage and enhance the value of their portfolio companies. Contacts with PE firms were provided by a large consultancy firm ${ }^{10}$, with the request to have subgroups of firms that varied by the contextual conditions we identified as important. Through this process, we gained access to six PE firms. We studied these PE firms by looking at multiple units of analysis, that is, the control arrangement put in place between the PE firm and specific portfolio companies (at the time of interviewing, the six PE firms had active investments in a total of 64 companies).

The PE firms were selected based on the following criteria. First, we sought variation in the ownership position taken. Some of the PE firms specialised in taking majority stakes (Firm M) or minority positions (Firms C, F) in companies, while for others the type of ownership position was not a primary consideration when making investment decisions (Firms A, I, X). Second,

\footnotetext{
${ }^{9}$ Our study is defined as 'embedded' because within the same PE firm under analysis more units are considered (i.e. the various portfolio companies in our case). In addition, we have studied some PE firms more in depth and then adopted literal and theoretical replications by selecting other cases to predict similar results or predict contrasting results for anticipatable reasons (Yin, 2009).

${ }^{10}$ This firm is not involved in the design of the mechanisms used by the PE firms to control portfolio companies.
} 
we considered the investment stage. Common to all PE firms were expansion capital investments, in which the PE firm provides financing to a firm with an established technology or market position to enable more rapid growth by, for example, increasing production capacity, furthering product development, or penetrating international markets. Many of these firms were run by the founding entrepreneurs. Other PE firms also engage in replacement investments (Firms A, F, I), in which existing shares are purchased from another PE firm or financial institution, while two PE firms also engaged in leveraged buyouts (Firm A, M, I, X). Firm $\mathrm{M}$ was active in seeking investments in firms undergoing family succession or transition to professional management. None considered start-up/early-stage or rescue/turnaround investments, preferring to focus on firms that had proven track records.

Third, we sought variation in the industry sectors invested. We selected PE firms that undertook investments in a wide range of industries, to examine whether and how their approach varied to controlling firms operating in different industry settings. However, each PE firm had certain guidelines and restrictions concerning which industries were to be disregarded. Common restrictions included investments into weapons, tobacco, and gambling industries. Other restrictions included real estate and financial services (Firms A, F, C) and capital goods (Firm M). These were generally put in place because of the perceived risk and uncertainty of these sectors following the global financial crisis. Firm $\mathrm{X}$ had particular guidelines to avoid firms operating in highly regulated and labour-intensive industries. Fourth, other dimensions considered were the size and geographical location of firms they invested in. Firm A concentrated on smaller sized enterprises with significant growth potential, while Firms F, I, X and $\mathrm{C}$ considered also medium sized operations. Firm $\mathrm{M}$ focused on larger investments (40 to $125 \mathrm{~m}$ Euro) in medium sized companies. In some cases the funds were used by the target company to make further business acquisitions. In terms of geographical location, Firms A and 
$\mathrm{C}$ invested only in companies that were in relatively close proximity (specific regions of Italy), while Firms F and I considered investments across Italy. Firm X specialised primarily in Italian firms with international operations, while Firm M made investments in companies located in the UK and continental Europe, including Italy. Key characteristics of the six PE firms are reported in Table 1.

<Insert Table 1 about here>

\subsection{Data Collection and Analysis}

Initially we conducted two interviews with consultants from the PE advisory arm of the consultancy firm. These interviews provided initial insights into the PE sector and general structure of PE firms in Italy, and allowed us to gain access to firms in this field, where the difficulty of access is readily acknowledged (Hardie \& MacKenzie, 2007; King, 2008). In addition to interviews with members from each of the six PE firms, we had the opportunity to interview three professionals from a legal firm specialised in PE agreements, to understand PE contracting in more detail. To triangulate our evidence, we analysed formal documents, including contractual agreements, company policies and procedures (e.g. rules and behaviour policies, company statutes and bylaws), as well as company websites, company presentations, and industry association reports. In a few cases we were also able to interview managers of the portfolio companies. In total we conducted 17 semi-structured interviews over six months (see Appendix A). The interviews lasted between one and two hours. The interviews started with background information concerning the firm and the interviewee. Then the respondent was asked to describe the characteristics of PE transactions and the control mechanisms they implemented to manage the relationship with the portfolio companies. We then asked respondents to describe the factors that were important in the selection and relative importance 
of these controls (see interview check list in Appendix B). While in the first phase of the field study we focused on the management control mechanisms employed, in the second phase we concentrated more on relative importance of control mechanisms and associated contextual factors. Almost all interviews were recorded and transcribed. For those that were not transcribed, detailed notes were taken during the interviews.

The comparative analysis of PE relationships within and across PE firms allowed us to use a replication logic to confirm or disconfirm insights derived from each firm. After the first three firms we were able to sketch a tentative framework to explain the relative emphasis of control mechanisms employed in PE relationships. The remaining three firms were conducted with the view to predict similar results (a literal replication) or contrast results but for anticipatable reasons (a theoretical replication) to refine the initial framework (Caglio \& Ditillo, 2017; Cooper \& Morgan, 2008; Yin, 2009). One important element of this process was that we allowed concepts to emerge from the data, rather than being directed by predefined hypotheses. We conducted comparative analyses to identify similar constructs and relationships, grouping relationships between PE firms and their portfolio companies according to emerging dimensions that were associated with variation in control combinations. Relevant emerging themes were related to the distinction between majority and minority ownership stakes and on the presence of an entrepreneur or professional manager in the portfolio company with the corresponding implications in terms of characteristics and emphasis of control mechanisms. We fine-tuned identified relationships, revisiting the data to check whether each relationship suggested the same pattern, using tables and associations to foster an iterative comparative exercise. From this process we constructed a framework that illustrates how control mechanisms are combined in particular ways to manage portfolio companies.

\section{Field Study Findings}


Our findings are presented according to the following logic. First, data related to the organization of the PE firms are presented. Second, the description of the control mechanisms that PE firms use to support and manage the portfolio companies are detailed. Third, descriptions of the factors associated with variation and relative importance of control mechanisms are outlined. We focus on how two main factors that we identified - equity arrangement and perceived cognitive style - influence the combination of control mechanisms adopted by PE firms.

\subsection{The Organization of PE firms}

The PE firm management structures are relatively similar. Typically there are at least two executive committees, which can have overlapping members; one that is concerned with identifying and making new investments and another that monitors the performance and relationship with existing portfolio companies. There are some variations in how the PE firms make decisions regarding portfolio firms. For instance, Firm F has multiple teams that manage the operations of a subset of portfolio firms, whereas Firm $M$ has three operating committees tasked with overseeing different decisions: strategic committee (e.g. reviewing and revising strategic plans on a 6 monthly basis), human resources and compensation committee (e.g. appointment of key managers, setting annual incentive targets), and special projects committee (e.g. implementation of key strategic initiatives).

Also common is that investments tend to occur in either of two ways. The first is through auctions, in which the PE firm engages in a competitive bidding process. The second is through proprietary transactions, in which the other transacting party may be another PE firm (secondary buyout), a parent company (division spinoff), or private owners or entrepreneurs. Proprietary transactions typically arise from tender submissions made to the PE firm or through 
personal and professional networks (e.g. financial institutions, investment banks, financial boutiques and advisories, consultants, CPAs, trade associations). In one instance the PE firm made initial contact with the company through cold-calling.

\subsection{Control Mechanisms Implemented by PE Firms}

The PE firms we examined implemented a wide range of control mechanisms to support and guide portfolio company managers (Groot \& Merchant, 2000; Dekker, 2004). In fact, the role of the PE firm is much more varied than simply inspecting and monitoring the activities of portfolio companies to reduce opportunistic behaviour. Rather, a primary purpose of control is to motivate opportunity search and influence decisions concerning the strategic direction of the company.

The most important thing we do is just try to educate in a way the management to do their best and to pay attention to the numbers $[\ldots]$ and the other point is that we are trying to stimulate their minds to look for new opportunities for growth (Investment Manager, Firm $M$ ).

In Firm F and Firm I, control mechanisms were the main way to influence the actions of the portfolio companies, more so than contractual arrangements, with perceived positive effects on the performance of the investment.

You can influence the course of action of the company not because you have the right, but because you have an idea, you have a proposal, you put it on the table and this is the right mind and you get two benefits. One is you get a positive news for the company, and the second is you have better trust from your partners. And whenever they have 
problem - my wife calls these 'the Friday Night calls' [...] they want to share with you the major real events of the week and they want to listen to your opinion about those events. This is a way and if you get this kind of confidence typically, not always but typically, the performance of the investment is much higher (Managing Partner, Firm I).

Our evidence points to which mechanisms are commonly adopted by PE firms to control their portfolio companies. These mechanisms are classified as contractual, results, behaviour, and social controls. A detailed list of controls in each category are reported in Table 2.

<Insert Table 2 about here>

\section{Contractual controls}

PE firms define decision rights and monitor the actions of portfolio companies by means of legal ordering, which comprises the writing and enforcement of contractual agreements. Common clauses placed in shareholder agreements related to exit rights (e.g. exit route, tag along, drag along, ${ }^{11}$ right of first refusal, redemption rights), board rights (e.g. number of seats, decision authority), voting rights, veto rights, managerial selection rights, cash flow rights, and liquidation rights. Interestingly, although there were some variations in contracts between investments, most of the contractual clauses implemented by each PE firm were relatively standardised. However, there was variation in the perceived importance of the different clauses.

\footnotetext{
${ }^{11}$ Tag-along rights (or co-sale agreements) refer to the ability of the minority shareholder to demand from a buyer the same conditions provided to the majority shareholder. Drag-along rights refer to the ability of the majority shareholder to force their partners to join them in selling their stakes to a buyer (Chemla, Habib \& Ljungqvist, 2007).
} 
Exit rights and liquidity rights are essential contractual provisions as PE firms are constrained by the limited life of the funds that they use to make acquisitions. All PE firms in our sample incorporated clearly specified liquidity and exit rights, although the level of detail stated, notably in terms of the exit route, was particularly stressed by Firms F and C. Control rights were also important for all PE firms. Firm F commented on the importance of having the right to veto decisions relating to extraordinary operations (e.g. acquisitions), approval of the business plan and annual budgets, managerial selection, and investments or expenses over a certain threshold. One particularly important right is determining the non-executive board directors, as it allows PE firms to appoint specific professionals who had expertise that they felt the company required. Decision rights for specific areas of expertise (e.g. international expansion, distribution channels) were often allocated to this individual. Control rights were in some cases stated contingently, typically dependent on the firm meeting financial performance benchmarks, but they were not seen to be particularly important as a contractual control, apart from instances where the firm had a significant amount of debt or additional future capital was to be provided.

Certain rights, such as the appointment or replacement of key managers, were often activated immediately. Firm A typically appoints a new CEO, CFO, and other key managers, while managers at all PE firms commented that the CFO was a critical intermediary between the portfolio company and the PE firm. This is because the CFO is often the only individual with sufficient understanding of, and ability to communicate, the financial position of the company. Even in PE firms that preferred continuity of personnel (Firms F, M, X), they would still consider appointing or replacing the $\mathrm{CFO}$, as they are perceived to be essential to the success of the investment. 
Out of these [contractual controls] the most critical is having a CFO that is able to make the right dialogue with the fund. The CFO is the person that drives all the critical aspects of the company and sometimes neither the entrepreneur nor the CEO knows (Senior Partner, Firm F).

All these contractual provisions represent important ways to regulate the relationship between the PE firm and the portfolio companies. Moreover, contracts provide the basis upon which other control mechanisms are selected. However, we find evidence that the main role of contracting is in formalising mutually understood investment objectives, rights and responsibilities, and as a means for developing trust, rather than being primarily an ex-post control tool. It plays an important role post-acquisition only if there is an irreparable breakdown in the relationship.

The main rule is never fight. Even if you lose money, you cannot fight. Because it is inefficient $[\ldots]$ Today we have a legal fight with one of our partners in the previous investment. It's three years, we are still there, in a very preliminary discussion $[\ldots]$ imagine, we can have the [investment fund] closed and still have the legal dispute, it doesn't make any sense (Managing Partner, Firm I).

Of course it happens that sometimes they do not respect the [contractual] clauses, but I have never taken the lawyers to enforce the respect of the clauses [...] the trust would have been under risk if I had used a strong approach (Senior Partner, Firm F).

\section{Results controls}


Apart from contracting, common results controls implemented are regular financial reporting and incentive compensation. Often these mechanisms are stipulated in contracts, which specify the frequency with which financial reports and other performance information had to be provided to shareholders. Apart from Firm A, PE firms usually required invested companies to provide monthly financial reports. Firm A stipulates quarterly reporting, as the firms they invest in often lack the systems and personnel to provide detailed financial reports on a more frequent basis, at least initially. Generally, financial reporting tends to be quite standardised across portfolio companies, although these may be complemented by unique performance indicators that relate to the specific industry, strategy, or context of the company.

The principal tool we use to monitor financial performance is regular formal reporting [...] we have a set of standard financial reports which are provided to the company, they're customized, of course, depending on the type of business (Managing Director, Firm C).

Financial incentives were seen as being particularly critical in efforts to align the economic interests of portfolio company top managers. In some instances, incentive structures for the second and third tiers of management were also implemented. There were three main incentive mechanisms. First, some of the PE firms ask company executives of the portfolio company to invest a certain amount of their own money in the firm (Firms C, F, I). This amount is calculated for instance on the basis of personal wealth or as a multiple of annual salary. Some PE firms also required the employees that are managing the investment to take an equity stake (Firms C, I). This not only incentivized the PE firm managers to 'fight for that investment' but provides an initial basis for building trust - the 'entrepreneur understands that you are a little bit like him' (Firm I). 
Second, are short-term incentives, including annual bonuses, granting of share options, and salary increases. These are typically tied to key financial metrics, such as turnover, profit, cash flow, and other budget and operational targets or they can be linked to the conclusion of a specific deal. Third, earn out clauses are implemented that provide a payment determined by whether or not, or the extent to which, the exit price of the firm exceeds a predetermined target. Another incentive mechanism, although less common, was sweat equity, which confers equity rights based on continued contributions in terms of time and effort by the entrepreneur. This is used to encourage an entrepreneur with specialised knowledge and skills, to remain with the company throughout the entire life of the investment.

We put in place two kinds of incentives, apart from sweat equity: one was linked to the sale of the business with our goal in terms of timing and price. With a maximum time and a minimum price $[\ldots]$ based on IRR and multiple of the investment. [...] and we also have an annual performance inventive which can be up to $30 \%$ of the salary of the top management, based on EBITDA and net debt (Managing Director A, Firm $X$ with reference to portfolio company X1).

\section{Behaviour controls}

A wide range of behaviour control mechanisms are also implemented by PE firms. Shareholder meetings and board meetings, typically monthly, were contractually specified in all instances, as was the right to call impromptu board meetings if extenuating circumstances arose. Management meetings and specialised committees (e.g. strategic review, human resources) were also important in many cases, as were company site visits, where PE firm managers were able to talk to lower level managers, employees, and clients. 
We sit in the board and we normally ask for a monthly board meeting. If there is a need we can have a weekly board meeting. But anyhow we normally have the right to call the board for a meeting, whatever the subject (Managing Partner, Firm I).

It's important for us to visit the companies often. At least every month, once a month we have a visit at the company site, speaking with people, if it's possible speaking also with clients. This kind of stuff is very, it's very important (Senior Partner, Firm F).

Business planning is another key behaviour control because it provides an initial agreement between the PE firm and the entrepreneurs or managers as to the strategic objectives and desired performance of the company over the life of the investment. Business planning also serves to define the role of the PE firm and extent of involvement in providing advice and resources. All PE firms we interviewed are actively involved in constructing the business plan at the start of the investment - one investment manager commented that at the start of the investment "we jump into the process $[\ldots]$ and help them to develop the budget or the business plan' (Firm M). If invested companies are performing well, then the level of involvement in future reviews and adaptations is less, but typically they retain the right to veto business plan revisions. Involvement in budgeting and operational planning varies between PE relationships, from the exercise of final approval to active involvement in all aspects of the planning process (e.g. determination of assumptions, costing resource requirements). PE firms also set various rules and procedures, in particular for how board meetings are to be conducted, but also in terms of boundaries around the strategic and operational activities of the company. This limits the discretion of company managers (e.g. the type of investments that they can make) without seeking formal approval. 


\section{Social controls}

Social controls and interpersonal relationships were also mentioned by all PE firms as being important for managing portfolio companies. PE firms leverage personal relationships that start at partner selection (i.e. the portfolio company). Appropriate partners are identified based on reputation, direct past knowledge, business networks and social ties, as well as specific criteria for identifying investments and the related entrepreneur and management team.

The hard criteria are the geographical location, sector and fundamentals. [...] Then we have a full set of soft criteria, which of course encompass the quality of management, its track record of management, organisational behaviour of management, goal orientation and of course all those soft psychological sometimes philosophical elements which underlie management action (Managing Director, Firm C).

Depending on the quality of the management, we do more also from a technical or numbers point of view or more on high level (Investment Manager, Firm M).

For some PE firms, existing management quality is an important consideration in initiating the relationship, and contributes to defining the extent of monitoring and control that the PE firm implements. The control mechanisms in place in the portfolio companies are another consideration. Depending on the level of sophistication, they can facilitate communication with, and control of, the invested company, albeit sometimes requiring specific adaptations to work effectively. 
When we bought, [the company] had very good reporting, with an ERP with complete reporting in place. The reporting was based on industrial standards, so it was not a standard P\&L in the way we are used to see it [...] So after the acquisition, we changed it, keeping their usual version for their decision-making, but adding also a standard P\&L in the sense we are used to thinking about it (Managing Director A, Firm X with reference to portfolio company X2).

Partner selection can be quite protracted. The managing director of Firm F commented that forming a relationship with an entrepreneur can begin two to three years prior to an investment agreement being reached. Particularly important is the development of trust and solidifying mutually agreeable expectations between the PE firm and the entrepreneur:

I think that it is a slow process in which you have to build trust every single day, reciprocal trust [between] yourself and the entrepreneur, and our role is to enter in confidence with the entrepreneur, to show the entrepreneur that we are not a vulture fund, we don't want to destroy the company that he created. We do not want to, to make the extra profits by destroying his life or his family. But it's, we try to demonstrate that, maybe doing in a different way, or giving us some governance or giving us some procedures is not only good for us but is also good for the company. So it's a process of trust building (Senior Partner, Firm F).

Selecting an appropriate partner represents the starting point for building an effective relationship with the portfolio company. Continuous interaction between the PE firm and the portfolio company to jointly set objectives, address problems, make key decisions, and 
coordinate activities, was noted as being important throughout the life of the investment, but particularly critical at the beginning.

We really pushed for a lot of meetings in the beginning. Because you really have to build a relationship [...] we have to know each other in terms of view about the company and so on. It requires a lot of effort and a lot of time but I think that must be done from day one and it is much more important than formal things (Managing Director A, Firm X, with reference to portfolio company X1).

In this way the PE firm managers activate commitment and motivation to generate positive results from the relationship and decrease the likelihood of opportunistic behaviour. However, the level of informal interaction can be more limited when the quality of professional management is high.

[Compared to another investment] there is a more senior CEO, the management team is stronger generally speaking, in terms of seniority and competence, $[\ldots]$ and there is less frequent interaction (Managing Director A, Firm X, with reference to portfolio company X3).

\subsection{Factors Associated with Variation of Control Mechanisms}

The previous section outlined the role and characteristics of the control mechanisms implemented by PE firms to manage portfolio companies. The presence of these mechanisms were generally observed across all PE relationships. However, their relevance and emphasis were not uniform, and various combinations of mechanisms were adopted more frequently in particular circumstances. We found several factors potentially affecting contractual rights and 
control mechanisms. ${ }^{12}$ However, from our analysis two dimensions emerged as being predominant in explaining the selection and relative importance of control mechanisms: (1) the equity arrangement between the PE firm and the portfolio company, and (2) the perceived cognitive style of the portfolio company's management which is, in most instances, related to whether the company is managed by an entrepreneur or by a management team. These factors emerged in our field study as particularly important because they affect, on the one hand, the decision-making processes taking place within the portfolio company and, on the other hand, the level of formal influence that the PE firm is able to exert.

\subsubsection{The Influence of the Equity Arrangement}

With reference to the equity arrangement the key distinction is between minority or majority stake investments. ${ }^{13}$ In minority stake investments, the specification of contractual clauses is particularly important:

Governance rules provide for a set of legal limits to the power of the majority shareholder $[\ldots]$ so we have all these important legal limitations which you set in the shareholder agreement. And that's particularly true when you are a minority shareholder versus when you are a majority (Managing Director, Firm C).

\footnotetext{
${ }^{12}$ Other factors influencing the choice of control mechanisms are: 1) Whether the company is family-owned, which increases the importance of informal communication and trust-building; 2) The method of investment, whether through an auction or a proprietary sale - in a proprietary sale the PE firm can establish direct contact with the entrepreneur or managers, whereas when the transaction takes place through an auction, the PE firms have limited exposure to the company and restricted access to owners and managers; 3) The presence of a professional intermediary in the process, which can improve information access prior to formalizing a contract and make it easier to gain the trust of an entrepreneur; 4) the level of debt of the portfolio company, which influences the tightness of financial covenants and decision rights specified in the contract; 5) the investment lifecycle stage, which influences the extent of contact between the PE firm and the portfolio company, and 6) the size of the portfolio company, with larger firms characterized by more sophisticated accounting and control mechanisms in place, enabling more frequent access to information with greater detail. Additional factors considered, such as PE firm objectives and portfolio company performance, did not appear to have much influence on the control mechanisms adopted.

${ }^{13}$ In nearly all relationships only one PE firm was involved in a portfolio company investment. For syndicated investments (i.e. multiple PE firms) that take majority ownership stakes, typically one PE firm is the lead investor and retains most of the control rights.
} 
In minority positions, contractual clauses need to be carefully negotiated with the majority shareholder(s). Certain control rights can be difficult to obtain as the majority shareholder (e.g. the entrepreneur) may be reluctant to give up their decision-making autonomy - 'when you are a minority investor it's much harder to obtain from the majority shareholder the power to veto' (Firm $C$ ). At the same time, some PE firms will attempt to introduce specific contractual clauses to limit the discretion of the majority stakeholders and the related management team:

In the contract, given that we are in minority position in the board of directors, we have the veto rights on extraordinary events, but not only that, also on ordinary management that goes beyond certain expense limits, as well as on strategic issues and the approval of the budget or the business plan which are approved with our vote (Investment Manager, Firm A, with reference to portfolio company A1).

Two contractual rights emerged from our analysis as necessary in most instances for a PE firm to invest as a minority shareholder. One was having access to financial and operational information in order to monitor and evaluate the performance of the company and its top managers. The second related to the timing and route of exiting the investment. Without clearly defined exit rights, the minority partner can be stuck in the investment if a buyer only wishes to take whole or majority ownership of the company, and the majority partners refuse the offer.

The most important aspect as a minority investor is the control of the exit route [...] it's always recommended to have a very clear idea of the way you want to go about exiting and setting it very clearly vis-a-vis with the other partners (Managing Director, Firm C). 
Exit rights may include drag-along and tag-along rights, and in some cases buy-back clauses, which ensure that if typical exit routes (e.g. trade sale, IPO) are unsuccessful, the PE firm can still exit the investment through selling their share of ownership to the majority shareholder at a predetermined price.

Although PE firms in minority positions will have access to financial and other performance information, and will often have at least one seat on the board of directors, the capacity to implement results and behaviour controls is otherwise limited. As such, social controls are the primary mechanisms through which PE firms influence the portfolio company. The general approach then is one that is 'softer' in terms of attempting to accommodate the views and desired direction of management.

In terms of attitude, when you are a minority investor you tend to [...] accommodate more the management decisions and you have a softer stance towards managers. It's a consequence of not being the ruler of a company (Managing Director, Firm C).

Influence is exerted through informal relationships that the PE firm develops with the portfolio company managers.

If the participation is a minority, however, we must have a direct contact that we try to create, with the entrepreneur, with the CEO, to try to have a more or less continuous control on what is, say, not the ordinary administration $[\ldots]$ but on what are strategic decisions in the company $[\ldots]$ it can also be an informal contact with the entrepreneur, where in the phone call once a week we try to understand what is happening, what we 
are doing, if there is a need to go to the company, if there is a need for our presence in the company (Investment Manager, Firm A).

In one minority investment, Firm $\mathrm{C}$ wished to learn more about the projects taking place within the firm that would need to be taken to the Board of Directors for addition financing approval. Rather than voice concerns about specific projects at the Board of Directors meeting, in which they have little formal authority, they obtained information through informal contact with key managers, and provided suggestions and guidance about where the firm should be investing its resources.

In general, social controls appeared to be relied upon more extensively than either results or behaviour controls when PE firms took minority ownership stakes. Social controls enable more timely monitoring and information retrieval, and avoid deteriorating the spirit of collaboration and trust that might be created in leveraging more formal mechanisms.

A company we invested [as minority shareholders] we specifically intended to communicate more informally with managers $[\ldots]$ we tended to have a softer procedure because clearly we don't want to spoil our relationships [...] we need access to management to have better information so we have a friendly collaborative attitude (Managing Director, Firm C, with reference to portfolio company C1)

The approach for majority stake investments is rather different - PE firms tend to rely more on contractual and formal control mechanisms. 
When you have the majority, because you have a higher degree of responsibility, you have to have a tougher stand, a more incisive attitude towards management and with the general stakeholders of the company because you want to protect yourself from risks $[\ldots]$ you may want to have a tougher role towards managers, you may want to implement more formal communication, formal tools towards managers (Managing Director, Firm C).

In majority positions, PE firms implement more rigorous financial controls and reporting procedures - 'if it is a majority stake, we try to have a frequent monitoring of numbers' (Investment Manager, Firm A). This enables a results-based control approach, whereby managers are granted more discretion and independence but made responsible by means of performance targets, while certain boundaries are introduced through behavioural controls, such as rules, procedures, and sanctions. In another portfolio company of Firm C, in which it had a majority stake, a number of critical performance issues were identified. In contrast to the informal and 'soft' approach taken in the case of the minority investment noted previously, performance issues were formally detailed in the Board of Director minutes following an extraordinary meeting, together with an outline of what the CEO was required to do to turnaround the situation. Three months later Firm $\mathrm{C}$ dismissed the CEO and appointed a replacement. For majority investments, the right to dismiss and appoint key personnel is a primary lever for influencing the strategic trajectory and performance of the portfolio company.

When we are a majority shareholder and we have responsibility over the management of the company we need to appoint managers. In some cases, we may retain former managers $[\ldots]$ but definitely we go forward with new managers if we think there is need for change (Managing Director, Firm C). 
The timing of the appointment of executives and managers is key because it may have an impact on the success of the transaction, given that the portfolio company will have its own specific style of management, which requires time to be modified.

Often we have a specific, peculiar management style and the transition to professional management cannot be brutal, we don't want it to be brutal or abrupt so we ask former managers to ensure handover (Managing Director, Firm C).

This is one reason why three PE firms noted that they preferred continuity of management teams even in majority ownership positions (Firms F, M, X). It can be difficult, though, to change the way in which managers operate within the portfolio companies, especially if the company is being run by the entrepreneur.

It's difficult to change, you know? To change the habits [of the entrepreneurs] because they were preparing, for example, quarterly income statements and no cash flows, no balance sheet. Now they are preparing a monthly package. But it took some time (Managing Director A, Firm X, with reference to portfolio company X1).

However, there are still occasions where managers may need to be replaced, and this is a particular benefit of being in a majority position.

Management team is an important point; for example, we don't really want to back companies where the management is going to leave after the deal. So it is quite important for us that there is a sort of continuity in the management team [... ] it's 
important to gain credibility towards them [...] but it happens that once we jump in, we realize that this management is not appropriate for the second phase of growth or to manage certain kinds of situations (Investment Manager, Firm M).

\subsubsection{The Influence of Perceived Cognitive Style}

Apart from the equity arrangement, our evidence showed that individual traits of the top managers of the portfolio company were important in the choice of control mechanisms. In particular, cognitive and decision-making traits were largely associated with whether the portfolio company is run by entrepreneurs or managers.

The difference [in control mechanisms] is if you talk about relations with a manager or with an entrepreneur (Managing Partner, Firm I).

Formal control mechanisms tend to be less effective in managing relationships with companies where managers have an entrepreneurial mindset. There is, however, still the need to monitor performance.

You have to monitor surely more because it is all in the hands of an entrepreneur [...]

So, in that case there, our commitment and our approach is certainly more intensive (Investment Manager, Firm A, with reference to portfolio company A1).

The entrepreneur owned $60 \%$ of the company and he was reluctant to accept a formal set of reporting [...] And that was really related to the nature, to the personal nature, the sort of attitude that this guy had [...] so we had to accept in this specific instance a less set of formal information. Conversely, we had really daily access to managers in 
an informal way. So we did make up for a lack of formal information exchange with more informal liaisons (Managing Director, Firm $C$, with reference to portfolio company C2).

Interviewees at Firm A and Firm F both commented that they attempted to introduce some degree of formalisation, such as regular meetings and standardized financial reporting, but this is not always possible.

We have difficulties when the portfolio company cannot produce those data. It's not able to provide us the information. This is a difficulty in controlling the firm (Investment Manager, Firm A).

Much of the capacity to influence decisions, then, comes about through reciprocal trust building and mutual understanding about the objectives of each party. PE firms attempt to develop close personnel relationships with entrepreneurs and seek to achieve compromise over the strategic direction of the firm and major investment decisions.

Relation, relation. It's moral persuasion; it's the ability to convince [...] if you are able to conquer the trust of the entrepreneur, he starts feeling that you are not a counterpart, you are a partner. When you are a partner, as in every partnership there is mutual trust, there is a mutual ability to influence even if you don't have the [contractual] right (Managing Partner, Firm I).

Contracts were still considered important for control. For instance, when much of the value of the firm is tied up in the knowledge capital of the entrepreneur, contracts are likely to include 
non-compete clauses. However, there were definite limits to the capacity of PE firms to enforce contractual rights. Provisions such as veto rights were rarely exercised when dealing with entrepreneurs, especially when the PE firm has a minority stake.

It allows you to create these relationships, this trust, together with entrepreneur. It is what you need, especially if you are a minority stake, because if you want to impose rules being in a minority, it doesn't work (Senior Partner, Firm F).

Even when the PE firm does have the contractual right to enforce a particular decision it can be problematic to do so. The managing director of Firm I explained that in one case a potential trade deal where the buyer wanted an outright purchase of the company was scuppered by the entrepreneur, even though the PE firm had all the contractual rights to proceed with the sale. In meeting with the prospective buyer, the entrepreneur exaggerated all the perceived weaknesses of the business and claimed how the company would cease to be financially viable without him being involved.

The only way we can solve this situation is not because you have the shareholders' agreement, but because you find a mutually satisfactory agreement (Managing Director, Firm I, with reference to portfolio company I1).

In contrast, PE firms viewed relationships with portfolio companies led by managers with managerial mindsets quite differently.

If you are talking with the manager, that makes a difference. Because a manager is somebody that works for you (Managing Partner, Firm I). 
PE firms place a greater reliance on results controls mechanisms, such as budgets and performance-based incentives, to monitor and influence the actions of managers. The development of shared expectations and objectives is also facilitated through processes such as budgeting.

If the management is good we monitor the budgeting process from a sort of high level point of view. They present the work, we discuss about the budget assumptions. If we think it is not ok, then they go back and change it, so there is a standard negotiation between the [PE firm] and the managers (Investment Manager, Firm M).

For PE firms in minority positions, contractual provisions, especially veto rights and control over certain decisions, are important safeguards to managerial discretion. In a majority position, although holding control rights, they tend not to be activated. Instead, the PE firm relies on the judgement of key managers, some of which they have selected.

[The PE firm] selects a manager and delegates to the management of the company, defines the objectives and makes resources available. From there, the manager is free to decide. There are moments in meetings in which the [PE firm representative] intervenes, since the owner has all the rights, but [they typically] try to help you without interfering in the activity. (CFO Portfolio Company M1, Firm M).

Finally, when PE firms are dealing with a professional management team, interpersonal interactions tend to be less intensive and formal channels of communication are more likely to be adhered to. 
We mainly go through the CEO, CFO, or head of Italy or head of Germany if we have something specific, but we don't go below [...] we have to respect the way the management is managing. (Managing Director A, Firm $X$, with reference to portfolio company X3).

\section{Discussion}

Our analysis reveals that there is a relatively common set of control mechanisms that PE firms implement to manage relationships with portfolio companies. In contrast to most studies of PE relationships, which in taking a financial contracting perspective assume that the relationship is coordinated primarily through ex-ante contractual specifications, we find that contracts are considered as a tool to be enforced only as a last resort. PE firms and portfolio companies want to 'keep it simple and avoid red tape' and often do not want to resort to the law to resolve conflicts (Macaulay, 1963). Contracts do however serve to formalise mutually understood objectives of the relationship, specify rights and responsibilities, and act as a basis for trustbuilding. Rather than being mechanisms primarily to enforce ex-post control, they instead play an integral role in providing the foundation upon which control can be effectively achieved through a wide range of mechanisms implemented by the PE firm. ${ }^{14}$ In particular, social controls were observed to play a critical role in many PE relationships.

While the presence of results, behaviour, and social control mechanisms were commonly observed across PE relationships, their relative importance varied significantly. While we observed several factors associated with the emphasis placed upon different control

\footnotetext{
14 This relationship between contract and controls is similar to what is described as internal and external corporate governance (see Roe, 2004).
} 
mechanisms, two factors emerged as being particularly central to understanding variation in control combinations: the equity arrangement and the perceived cognitive style of top management in the portfolio company.

PE firms with minority interest have less capacity to exert formal control. For this reason, some contractual specifications are particularly important for minority partners, such as veto rights, and PE firms generally have at least one seat on the board of directors to enable some degree of hierarchical monitoring. But beyond board level interactions and certain contractual rights, influence over firm activities must be 'negotiated on an ongoing basis' (Gulati \& Singh, 1998, p. 793). Initial partner selection is critical as the ability to replace personnel ex-post can be limited. PE firms invest in social interactions that build trust between parties, such as site visits, frequent informal communication, and an emphasis on advice-giving and joint problem solving, in order to influence the direction of the invested firm.

In contrast, PE firms with majority interest have a significantly greater capacity to implement formal controls. Control arrangements share similarities with how a parent company controls a subsidiary, with mechanisms including well-defined authority structures, formal planning and approval processes, operating procedures, and specified processes for dispute resolution (Baliga \& Jaeger, 1984). Results-based controls, such as budgeting and incentive structures, are particularly important, providing direct means to clarify and motivate desired performance (Goold et al., 1994). These formal mechanisms reduce the need for social control processes such as intensive relational development, although replacement of personnel is important to ensure the firm has adequate technical and managerial capabilities to achieve desired objectives. 
In portfolio companies led by entrepreneurs, formal contracting can become prohibitively costly or difficult to enforce. Firm value is largely derived from the tacit understandings and non-codified knowledge of the entrepreneur (Dyer \& Singh, 1998; Schepker et al., 2014). Entrepreneurs also have a greater tendency to defy or work around standardized procedures that limit autonomy and flexibility. Rather, the control efforts of PE firms focus on building trust and mutual understanding, such that exchanges are regulated through 'unwritten and largely nonverbalized sets of congruent expectations and assumptions held by transacting parties about each other's prerogatives and obligations' (Ring \& Van de Ven, 1994, p. 100). However, certain contractual specifications and compensation mechanisms tying the entrepreneur to the firm, such as non-compete clauses and equity-based incentives, are considered important, particularly when their idiosyncratic knowledge and capabilities are central to the success of the organization (Arthurs et al., 2009). If not already in place, PE firms implement financial and performance reporting systems as a means to monitor performance, but little reliance is placed on these systems to actively influence managerial behaviours.

In portfolio companies led by individuals with a professional managerial mindset, greater reliance tends to be placed on formal contracting and results-based control mechanisms. Executives with managerial cognition are more acquainted with 'accountability and compensation schemes, the structural coordination of business activities across various units, and quantifiable budgets' in making decisions and justifying prior actions (Wright et al., 2000, p. 592). Compensation based on short-term financial targets, regular financial reporting, standardized decision rules, and formalized planning procedures fit the preference of these executives for structured work environments and analytical, systematic decision-making (Brigham et al., 2007). Moreover, organisations led by teams with managerial mindsets are likely to have more sophisticated reporting and control mechanisms already in place. 
By interweaving the effects of the equity arrangement and perceived cognitive style, we derive a framework of the control combinations that PE firms implement to manage their relationships with portfolio companies. The framework is presented in Figure 1. ${ }^{15}$

<Insert Figure 1 about here>

In relationships characterised by minority ownership and entrepreneurial cognition, PE firms typically have fewer contractual rights due to their minority stake, although clauses such as non-compete and exit rights are often a prerequisite for investment. PE firms also have limited capacity to impose formal control mechanisms. As such, it is necessary to leverage on social control to influence the entrepreneur's behaviour towards the achievement of mutually beneficial objectives. Partner selection - choosing the right firm and the corresponding individual (i.e. the entrepreneur) - is essential for developing a relationship based on reciprocal trust. The success of the investment is dependent on the ability of the PE firm to exploit the tacit strategic and business expertise of the entrepreneur. Continuous interaction and support in decision making and problem solving contributes to overcoming resistance to change and in persuading the entrepreneur to seek novel ways to generate growth.

PE firms engaging in relationships with majority ownership and entrepreneurial cognition are more inclined to implement formalised control mechanisms. Portfolio companies are characterised by decision making based on personal convictions and informal routines, and the imposition of bureaucratic control mechanisms by PE firms can create conflict with

\footnotetext{
15 The framework represents the relationship between a PE firm and a portfolio company. Each quadrant is supported by multiple PE relationships that we observed, both across and within the six PE firms we examined.
} 
entrepreneurs who have an established 'way of doing things.' Yet some degree of formalisation can help the PE firm to overcome embedded rigidities and resistance to change, necessary to take advantage of growth opportunities. In order to alter the strategic direction of the company PE firms will often appoint key personnel in the firm, such as the CEO, and introduce more formal decision-making processes to foster greater accountability for increasing firm value. If the portfolio company has unsophisticated results controls, the PE firm will invest in developing more detailed and frequent performance reporting systems. Over time the management structure is adjusted to try to combine the strategic knowledge and operational know-how of the entrepreneur with a more formal management structure that focuses the company towards greater value generation.

In relationships typified by majority ownership and managerial cognition, PE firms are able to rely upon a results-based control approach, by monitoring the achievement of performance targets that have been mutually agreed upon. The CEO and the management team in many cases will retain discretionary power on most strategic and operational decisions regarding how to achieve strategic objectives (Wright et al., 2001), with the PE firm intervening only when objectives are not being met or the proposed strategic plans are deemed inadequate. As majority owners, PE firms retain most control rights, including those to appoint and replace key personnel. The most common appointment is the CFO, who acts as the primary intermediary between the PE firm and the portfolio company. Regular interactions between the PE firms and portfolio companies mean that the relationship is not limited to a strict principal-agent approach to monitoring (Sapienza \& Korsgaard, 1996; Cable \& Shane, 1997).

Finally, in relationships characterised by minority ownership and managerial cognition, the extent of formal control that can be exercised by the PE firm is constrained. Because the ability 
to influence managerial behaviours post-investment is limited, contracts play a more decisive role. Certain clauses are particularly important, such as selection rights, voting and board decision rights, as well as clear specification of exit rights. PE firms in minority positions are limited in the number of seats that they have on the board, which is often only one. Seats are either assigned to a member of the PE firm, or the firm selects outsiders with certain competencies and expertise that they feel are necessary for company growth. PE firms may also specify that the designated board member has rights over decisions concerning a particular strategic area (e.g. international expansion). Other decision-rights that are negotiated are usually state-contingent, for instance, transferring power to the PE firm only when performance falls outside specified thresholds. In order to influence the general strategic direction of the firm, PE firms frequently make use of informal communication channels, through the majority shareholder or key managers in the firm.

These control combinations have some degree of correspondence with control archetypes and packages depicted in inter-organizational control research (Caglio \& Ditillo, 2008). The combination for entrepreneurial cognition and minority ownership has similarities to trustbased control patterns (Langfield-Smith \& Smith, 2003; van der Meer-Kooistra \& Vosselman, 2000). In these relationships, parties are bound by relational accountability, while contractual clauses are relatively non-specific and formal mechanisms such as accounting serve as a basis for information sharing than as a strict form of monitoring. Coordination through relational ties is an important part of control combinations for relationships characterised by managerial cognition and minority ownership too, but ex-ante contracting plays a more important role in acting as a safeguard and providing a basis for the initial formation of the relationship. This represents a hybridised pattern of contractual and social control and bears some degree of resemblance with the consultation-based control pattern described by Kamminga and Van der 
Meer-Kooistra (2007). Control combinations adopted by PE firms with majority ownership are similar to hierarchical and bureaucratic control patterns, with relatively detailed contracts and an ex-post reliance on results and behaviour control mechanisms to ensure contractual obligations are met (Langfield-Smith \& Smith, 2003; van der Meer-Kooistra \& Vosselman, 2000). This similarity is particularly apparent when top managers exhibit managerial cognition. However, in the case of majority ownership and entrepreneurial cognition, the control combination is a weaker form of bureaucracy, as there is a need to balance entrepreneurial peculiarities with more formalized mechanisms.

While there are similarities in the patterns of control observed, our framework deviates from prior literature in terms of the primary factors that influence the choice of control combination. The main explanatory factors of control choices in inter-organizational research are transactional traits (e.g. asset specificity, programmability) and environmental characteristics (e.g. risk, uncertainty), while party qualities have been less instrumental (Caglio \& Ditillo, 2008). Our analysis highlights a specific party trait - the perceived cognitive style - as an important factor for understanding variation in control combinations in PE relationships. The second factor, the equity arrangement, is an important variable in explaining governance structures (Fama \& Jensen, 1983). In our analysis, we show that the equity position taken by the PE firm, either minority or majority ownership, has a significant role in determining which control mechanisms can be effectively activated by the PE firm to manage relationships with invested companies.

Although we did not explicitly investigate how control mechanisms operate jointly, our field study evidence points to several interdependencies that occur in each combination (Bedford 2020; Grabner \& Moers, 2013). One interdependency between control types was observed in 
relationships where PE firms take minority stakes in organizations led by entrepreneurs. In these relationships, PE firms place significant reliance on social controls to build trust and mutual understanding to shape the direction and growth opportunities of the company. Results and behaviour controls are used only to a limited extent, to avoid undermining trust and prevent activating resistance or conflict (Cao \& Lumineau, 2015). Social controls can reduce the benefit of results control, as trust and relational understandings reduce the need for monitoring and other formal means to reduce opportunistic behaviour (Gulati, 1995). As such, social and formal controls are observed to be substitutes, as increasing the emphasis on one control reduces the benefits received from the other.

Our evidence is also consistent with interdependencies that arise between contracts and control mechanisms. In minority ownership positions with managerial cognition, PE firms make greater use of contractual provisions to ensure some degree of ex-post control. Clear contractual rights and responsibilities, particularly regarding decision rights, veto rights, and designation of board members with particular expertise, can create a platform that encourages knowledge sharing and commitment to shared objectives (Poppo \& Zenger, 2002). In contrast to top managers with entrepreneurial cognition, use of formal contracting is less likely to cause conflict or be perceived as undermining trust with personnel that have a more managerial mindset. Social control also facilitates parties arriving at mutually agreeable outcomes in circumstances that could not be foreseen at the time of investment. Hence, we see contracting functioning as a complement to social controls in this context. In relationships with majority ownership, contracting and formal controls are seen to have complementary effects. The key contractual right is personnel selection. Selecting managers that bring both professional expertise as well as the capability to work alongside entrepreneurs enables a more formalised control structure to be implemented. Similarly, formal controls, such as incentives tied to 
budgets and other performance targets, enhance the benefits received from selecting personnel (Abernethy et al., 2015), as these increase motivation and alignment to the PE firm's objectives.

\section{Conclusions}

This study investigated the control mechanisms adopted by PE firms to control their portfolio companies and the factors that explain their variation and relative importance. We depart from the majority of prior financial contracting literature, which focuses predominantly on leveraged buyouts of publicly listed companies from an agency perspective, by examining PE transactions that involve private small-to-medium enterprises and family-owned firms, where entrepreneurship, managerial succession, and market expansion are distinctive features. As agency costs are not a significant concern in this context, we focused on the combinations of control mechanisms PE firms put in place to manage their relationships with portfolio companies.

Through an analysis of evidence collected from six PE firms, we contribute to the literature in several ways. First, our study reveals that PE firms implement a wide range of control mechanisms beyond formal contracting and governance mechanisms to manage relationships with portfolio companies. In contrast to perspectives common in economic and finance literatures, we found contracts to function primarily as a means for ex-ante determination of objectives, rights and responsibilities, and incentives, and as a basis for developing trust, rather than being tools for ex-post enforcement. Second, we have provided evidence on the central role of social control in PE relationships in developing trust, mutual understanding, and a collaborative spirit. Social controls also help to facilitate information exchange to reduce information asymmetry, support mutual learning, and provide an informal means for the PE firm to influence the strategic direction of the portfolio company. 
Third, we demonstrate how two factors, the equity arrangement and the perceived cognitive style of the portfolio companies' management team, shape the control combinations that PE firms rely upon to achieve their objectives. In particular, the distinction between entrepreneurial and managerial cognition points to the importance of exploiting entrepreneurial competencies by developing trust and cooperation for the former, as opposed to aligning managerial incentives for the latter. The main difference in implications between minority and majority ownership stakes is the need to leverage social controls and informal relationships in the former case as opposed to more formalised control mechanisms in the latter, with the CFO representing an important trait d'union between the PE firm and the portfolio companies. In considering these two factors jointly, we developed a framework of four control combinations or packages that are aligned to a particular contextual setting. Our analysis of these control combinations also pointed to the potential interdependencies that arise between different control mechanisms. Extending these insights is an important area for future research.

Our study has certain limitations. One is that the study is restricted to PE firms in a single country. Civil law countries such as Italy tend to have fewer legal remedies available relative to common law countries (Fiss \& Zajac, 2004). This may contribute to the PE firms we analysed relying more heavily on social controls and relational governance (Hoskisson et al., 2004). Future research should explore the control choices made by PE firms in other national or supra-national settings (Malmi et al., 2020). Additionally, PE firms in our sample were generally focused on investments in small to medium sized companies. It may be that a less active and more transactional approach to control, reflecting conventional agency-theory expectations, is more evident in PE firms that manage deals of significantly greater size. Another limitation is that in almost all active investments of the PE firms examined, there was only one PE firm involved. However, it is not uncommon for multiple PE firms to jointly invest 
in a portfolio company. It would be interesting to investigate how control amongst each party is organized.

Furthermore, although there were exceptions, most investments were made in Italian companies. This may enable social control to work more effectively, especially when PE firm members are able to regularly interact face-to-face with portfolio company managers. Examining how PE firms investing in foreign companies manage their relationships would be another avenue for future research. Another potential limitation is that while we attempted to explore a range of contextual factors, there are likely to be other factors that will influence the choice of control mechanisms in PE relationships, such as the quality of management in the target company, and these could be considered in future research. Additionally, it is possible that some situations in our typology are more effective than others. In particular, situations where there is majority ownership and entrepreneurial mindset may be more challenging to achieve desired performance outcomes. Researchers could investigate whether control combinations across different conditions in our framework are equivalent in terms of performance or whether some perform better than others. Finally, other practices may be relevant for enhancing the value of PE investments beyond the control mechanisms we identified in this study. Given that the underpinning objective of PE is to maximize returns to investors, it is somewhat surprising that the application of value-based management (VBM) practices, such as value-driver analysis, were not more widely observed in our field study (Burkert \& Lueg, 2013; Malmi \& Ikäheimo, 2003). This is perhaps due to the focus of the PE firms we examine on investments in small-to-medium sized enterprises, and future research examining larger investments may gain insight into the application of VBM in the PE setting. Despite these limitations, we hope this study will provide an impetus for further research into 
the control combinations of PE relationships and the role they play in different institutional and organizational contexts. 


\section{References}

Abernethy, M. A., Dekker, H. C., \& Schulz, A. K. D. (2015). Are employee selection and incentive contracts complements or substitutes? Journal of Accounting Research, 53(4), 633-668.

Acharya, V, \& Kehoe, C. (2008). Corporate Governance and Value Creation Evidence from Private Equity. Working Paper.

Aghion, P., \& Bolton, P. (1992). An incomplete contracts approach to financial contracting. The Review of Economic Studies, 59(3), 473-494.

Aguilera, R. V., Filatotchev, I., Gospel, H., \& Jackson, G. (2008). An organizational approach to comparative corporate governance: Costs, contingencies, and complementarities. Organization science, 19(3), 475-492.

Allinson, C. W., \& Hayes, J. (1996). The cognitive style index: A measure of intuition-analysis for organizational research. Journal of Management studies, 33(1), 119-135.

Arthurs, J. D., Busenitz, L. W., Hoskisson, R. E., \& Johnson, R. A. (2009). Firm-specific human capital and governance in IPO firms: Addressing agency and resource dependence concerns. Entrepreneurship Theory and Practice, 33(4), 845-865.

Bacon, N., Wright, M., Meuleman, M., \& Scholes, L. (2012). The impact of private equity on management practices in European buy-outs: short-termism, Anglo-Saxon, or host country effects? Industrial Relations: A Journal of Economy and Society, 51, 605-626.

Baliga, B. R., \& Jaeger, A. M. (1984). Multinational corporations: Control systems and delegation issues. Journal of International Business Studies, 15(2), 25-40.

Baker, G. P., \& Wruck, K. H. (1989). Organizational changes and value creation in leveraged buyouts. Journal of Financial Economics, 25, 163-190.

Baron, R. (1998). Cognitive mechansisms in entrepreneurship: Why and when entrepreneurs think differently than other people. Journal of Business Venturing, 13, 275-294.

Bedford, D. S. (2020). Conceptual and empirical issues in understanding management control combinations. Accounting, Organizations and Society, 101187.

Bedford, D. S., \& Malmi, T. (2015). Configurations of control: An exploratory analysis. Management Accounting Research, 27, 2-26.

Bedford, D. S., Malmi, T., \& Sandelin, M. (2016). Management control effectiveness and strategy: An empirical analysis of packages and systems. Accounting, Organizations and Society, 51, 12-28.

Bernstein, S., \& Sheen, A. (2016). The operational consequences of private equity buyouts: Evidence from the restaurant industry. The Review of Financial studies, 29(9), 2387-2418.

Bernstein, S., Lerner, J., Sorensen, M., \& Strömberg, P. (2017). Private equity and industry performance. Management Science, 63(4), 1198-1213.

Beuselinck, C., Deloof, M., \& Manigart, S. (2008) Private Equity Investments and Disclosure Policy. European Accounting Review, 17(4), 607-639.

Bienz, C. and Walz, U., 2010. Venture capital exit rights. Journal of Economics \& Management Strategy, 19(4), 1071-1116.

Bloom, N., Sadun, R., \& Van Reenen, J. (2015). Do private equity owned firms have better management practices? American Economic Review, 105(5), 442-46.

Bottazzi, L., Da Rin, M., \& Hellman, T. (2008). Who are the active investors? Evidence from venture capital. Journal of Financial Economics, 89, 488-512.

Brigham, K. H., De Castro, J. O., \& Shepherd, D. A. (2007). A Person-Organization Fit Model of Owner-Managers' Cognitive Style and Organizational Demands. Entrepreneurship Theory and Practice, 31(1), 29-51.

Bruining, H., \& Wright, M. (2002). Entrepreneurial orientation in management buy-outs and the contribution of venture capital. Venture Capital: An International Journal of Entrepreneurial Finance, 4(2), 147-168.

Bruining, H., Bonnet, M., \& Wright, M. (2004). Management control systems and strategy change in buyouts. Management Accounting Research, 15, 155-177.

Burkert, M., \& Lueg, R. (2013). Differences in the sophistication of Value-based Management-The role of top executives. Management accounting research, 24(1), 3-22. 
Busenitz, L. W., \& Barney, J. B. (1997). Differences between entrepreneurs and managers in large organizations: Biases and heuristics in strategic decision-making. Journal of business venturing, 12(1), 9-30.

Cable, D. M., \& Shane, S. (1997). A prisoner's dilemma approach to entrepreneur-venture capitalist relationships. Academy of Management review, 22(1), 142-176.

Caglio, A., \& Ditillo, A. (2008). A review and discussion of management control in inter-firm relationships: Achievements and future directions. Accounting, Organizations and Society, 33(7-8), 865-898.

Caglio, A., Ditillo, A. (2017) 'The Field Research Method as applied to Behavioral Accounting Research: Case Studies' in T. Libby and L. Thorne (eds.), Behavioral Accounting Research, Routledge.

Cao, Z., \& Lumineau, F. (2015). Revisiting the interplay between contractual and relational governance: A qualitative and meta-analytic investigation. Journal of Operations Management, 33, 15-42.

Carson, S. J., Madhok, A., \& Wu, T. (2006). Uncertainty, Opportunism, and Governance: The Effects of Volatility and Ambiguity on Formal and Relational Contracting. Academy of Management Journal, 49(5), 1058-1077.

Chemla, G., Habib, M. A., \& Ljungqvist, A. (2007). An analysis of shareholder agreements. Journal of the European Economic Association, 5(1), 93-121.

Christner, C. H., \& Strömsten, T. (2015). Scientists, venture capitalists and the stock exchange:The mediating role of accounting in product innovation. Management Accounting Research, 28, 5067.

Cooper, D. J. \& Morgan, W., 2008, 'Case study research in accounting', Accounting Horizons 22 (2), 159-178.

Daily, C. M., Dalton, D. R., \& Rajagopalan, N. (2003). Governance through ownership: Centuries of practice, decades of research. Academy of Management Journal, 46(2), 151-158.

Davila, A., \& Foster, G. (2005). Management accounting systems adoption decisions: Evidence and performance implications from early-stage/startup companies. The Accounting Review, 81(4), 1039-1068.

Denis, D. J. (2004). Entrepreneurial finance: an overview of the issues and evidence. Journal of Corporate Finance, 10(2), 301-326.

Dekker, H. C. (2004). Control of inter-organizational relationships: Evidence on appropriation concerns and coordination requirements. Accounting, Organizations and Society, 23, 27-49.

Dekker, H. C. (2008). Partner selection and governance design in interfirm relationships. Accounting, Organizations and Society, 33, 915-941.

Dyer, J. H., \& Singh, H. (1998). The relational view: cooperative strategy and sources of interorganizational competitive advantage. Academy of Management Review, 23, 660-679.

Fama, E. F., \& Jensen, M. C. (1983). Separation of ownership and control. The Journal of Law and Economics, 26(2), 301-325.

Fenn, G. W., Liang, N., \& Prowse, S. (1997). The private equity market: An overview. Financial Markets, Institutions \& Instruments, 6(4), 1-106.

Fiss, P. C., \& Zajac, E. J. (2004). The diffusion of ideas over contested terrain: The (non) adoption of a shareholder value orientation among German firms. Administrative science quarterly, 49(4), 501-534.

Gompers, P., Kaplan, S. N., \& Mukharlyamov, V. (2016). What do private equity firms say they do? Journal of Financial Economics, 121(3), 449-476.

Goold, M., Campbell, A., \& Alexander, M. (1994). How corporate parents add value to the stand-alone performance of their businesses. Business Strategy Review, 5(4), 33-55.

Gorman, M., \& Sahlman, W. A. (1989). What do venture capitalists do? Journal of business venturing, 4(4), 231-248.

Grabner, I., \& Moers, F. (2013). Management control as a system or a package? Conceptual and empirical issues. Accounting, Organizations and Society, 38(6-7), 407-419.

Graebner, M. E., \& Eisenhardt, K. M. (2004). The seller's side of the story: Acquisition as courtship and governance as syndicate in entrepreneurial firms. Administrative Science Quarterly, 49, 366403. 
Granlund, M., \& Taipaleenmäki, J. (2005). Management control and controllership in new economy firms - a life cycle perspective. Management Accounting Research, 16(1), 21-57.

Groot, T. L. C. M., \& Merchant, K. A. (2000). Control of international joint ventures. Accounting, Organizations and Society, 25, 579-607.

Grossman, S. J., \& Hart, O. D. (1986). The costs and benefits of ownership: A theory of vertical and lateral integration. Journal of political economy, 94(4), 691-719.

Gulati, R. (1995). Does familiarity breed trust? The implications of repeated ties for contractual choice in alliances. Academy of management journal, 38(1), 85-112.

Gulati, R., \& Singh, H. (1998). The architecture of cooperation: managing coordination costs and appropriation concerns in strategic alliances. Administrative Science Quarterly, 43, 781-814.

Hardie, I., \& MacKenzie, D. (2007). Assembling an economic actor: the agencement of a Hedge Fund. The Sociological Review, 55(1), 57-80.

Hoetker \& Mellewigt, 2009, Choice and performance of governance mechanisms: Matching alliance governance to asset type. Strategic Management Journal, 30, 1025-1044.

Hoskisson, R. E., Yiu, D., \& Kim, H. (2004). Corporate governance systems: Effects of capital and labor market congruency on corporate innovation and global competitiveness. The Journal of High Technology Management Research, 15(2), 293-315.

Jakobsen, M. (2017). Consequences of intensive use of non-financial performance measures in Danish family farm holdings. Qualitative Research in Accounting \& Management, 14(2), 137-156.

Jensen, M. C. (1989). Eclipse of the public corporation. Harvard Business Review, 67(5), 61-74.

Kamminga, P. E., \& Van der Meer-Kooistra, J. (2007). Management control patterns in joint venture relationships: A model and an exploratory study. Accounting, Organizations and Society, 32(12), 131-154.

Kaplan, S. N., \& Schoar, A. (2005). Private equity performance: Returns, persistence, and capital flows. The Journal of Finance, 60(4), 1791-1823.

Kaplan, S. N., \& Strömberg, P. (2001). Venture capitals as principals: contracting, screening, and monitoring. American Economic Review, 91(2), 426-430.

Kaplan, S. N., \& Strömberg, P. (2003). Financial contracting meets the real world: An empirical analysis of venture capital contracts. Review of Economic Studies, 70, 281-315.

Kaplan, S. N., \& Strömberg, P. E. (2004). Characteristics, contracts, and actions: Evidence from venture capitalist analyses. The Journal of Finance, 59(5), 2177-2210.

Kaplan, S. N., \& Strömberg, P. (2009). Leveraged buyouts and private equity. Journal of Economic Perspectives, 23(1), 121-146.

King, B. L. (2008). Strategizing at leading venture capital firms: of planning, opportunism and deliberate emergence. Long Range Planning, 41(3), 345-366.

King, R., \& Clarkson, P. (2015). Management control system design, ownership, and performance in professional service organisations. Accounting, Organizations and Society, 45, $24-39$.

Kruis, A. M., Speklé, R. F., \& Widener, S. K. (2016). The levers of control framework: An exploratory analysis of balance. Management Accounting Research, 32, 27-44.

Langfield-Smith, K., \& Smith, D. (2003). Management control systems and trust in outsourcing relationships. Management Accounting Research, 14(3), 281-307.

Lehn, K., \& Poulsen, A., (1989). Free cash flow and stockholder gains in going private transactions. Journal of Finance, 44, 771-787.

Lerner, J. (1995). Venture capitalists and the oversight of private firms. Journal of Finance, 50(1), 301318.

Macaulay, S. (1963). Non-contractual relations in business: A preliminary study. American Economic Review, 28, 55-69.

Malmi, T., \& Ikäheimo, S. (2003). Value Based Management practices-some evidence from the field. Management Accounting Research, 14(3), 235-254.

Malmi, T., Bedford, D. S., Brühl, R., Dergård, J., Hoozée, S., Janschek, O., Willert, J., Ax, C., Bednarek, P., Gosselin, M., Hanzlick, M., Israelsen, P., Johannson, D., Madsen, D. O., Rohde, C., Sandelin, M., Stromsten, D., \& Toldbod, T. (2020). Culture and management control interdependence: An analysis of control choices that complement the delegation of authority in Western cultural regions. Accounting, Organizations and Society, 101116. 
McKinsey (2019). Private markets come of age: McKinsey Global Private Markets Review. McKinsey \& Company.

Merchant, K. A., \& Van der Stede, W. A. (2017). Management control systems. Performance measurement, evaluation and incentives (4th ed.). Harlow, Essex: Prentice Hall Pearson Education Limited.

Metrick, A., \& Yasuda, A. (2011). Venture capital and other private equity: A survey. European Financial Management, 17(4), 619-654.

Miron-Spektor, E., Erez, M., \& Naveh, E. (2011). The effect of conformist and attentive-to-detail members on team innovation: Reconciling the innovation paradox. Academy of Management Journal, 54(4), 740-760.

Mitchell, R. K., Busenitz, L. W., Bird, B., Gaglio, C. M., McMullen, J. S., Morse, E. A. \& Smith, J. B. (2007). The Central Question in Entrepreneurial Cognition Research. Entrepreneurship Theory and Practice, 31(1), 1-27.

Moskowitz, T.J. and Vissing-Jørgensen, A., 2002. The returns to entrepreneurial investment: A private equity premium puzzle?.American Economic Review, 92(4), 745-778.

Nama, Y., Lowe, A. (2014). The 'situated functionality' of accounting in private equity practices: A social 'site' analysis. Management Accounting Research. 25, 284-303.

Ouchi, W. G. (1979). A conceptual framework for the design of organizational control mechanisms. Management Science, 25, 833-848.

Poppo, L., \& Zenger, T. (2002). Do formal contracts and relational governance function as substitutes or complements? Strategic Management Journal, 1, 109-26.

Ring, P. S., \& Van de Ven, A. H. (1994). Developmental processes of cooperative interorganizational relationships. Academy of Management Review, 19, 90-118.

Roe, M.J., 2005. The institutions of corporate governance. In: Handbook of new institutional economics (pp. 371-399). Springer, Boston, MA.

Ryan, B., Scapens, R. W. \& Theobald, M. (2002) Research method and methodology in Finance and Accounting, London, UK: Thompson.

Sapienza, H. J., \& Korsgaard, M. A. (1996). Procedural justice in entrepreneur-investor relations. Academy of Management Journal, 39(3), 544-574.

Scapens, R. W. (1990). Researching management accounting practice: the role of case study methods. The British Accounting Review, 22(3), 259-281.

Schepker, D. J., Oh, W-Y., Martynov, A., \& Poppo, L. (2014). The many futures of contracts: Moving beyond structure and safeguarding to coordination and adaptation. Journal of Management, 40(1), 193-225.

Simons, R. (1995). Levers of Control (Boston: Harvard Business School Press).

Speckbacher, G., \& Wentges, P. (2012). The impact of family control on the use of performance measures in strategic target setting and incentive compensation: A research note. Management Accounting Research, 23(1), 34-46.

Strömberg, D. (2007). The new demography of private equity.. In Lerner, J \& Gurung, A (eds), The Global Impact of Private Equity Report 2008: Globalization and Alternative Investments. Working Papers, World Economic Forum, 1, 3-26.

Uzzi, B. (1997). Social structure and competition in interfirm networks: The paradox of embeddedness. Administrative Science Quarterly, 42(1), 35-67.

Van der Meer-Kooistra, J., \& Vosselman, E. G. (2000). Management control of interfirm transactional relationships: the case of industrial renovation and maintenance. Accounting, Organizations and Society, 25(1), 51-77.

Wright, M., Hoskisson, R. E., Busenitz, L. W., \& Dial, J. (2000). Entrepreneurial growth through privatization: The upside of management buyouts. Academy of Management Review, 25(3), 591600.

Wright, M., Hoskisson, R., \& Busenitz, L. (2001) Firm rebirth: Buyouts as facilitators of strategic growth and entrepreneurship. Academy of Management Executive, 15(1), 111-25

Wright, M., Amess, K., Weir, C., \& Girma, S. (2009). Private equity and corporate governance: Retrospect and prospect. Corporate Governance: An International Review, 17(3), 353-375.

Wruck, K. H. (2008). Private equity, corporate governance, and the reinvention of the market for corporate control. Journal of Applied Corporate Finance, 20(3), 8-21. 
Yin, R., (2009). Case study research: Design and methods. Beverly Hills, CA: Sage Publishing. 
Table 1

Characteristics of PE firms

\begin{tabular}{|c|c|c|c|c|c|c|}
\hline & Firm M & Firm C & Firm $\mathrm{X}$ & Firm F & Firm I & Firm A \\
\hline \multicolumn{7}{|l|}{ Structure } \\
\hline Number of executives & 7 & 5 & 3 & 20 & 10 & 14 \\
\hline Number of funds & 1 & 1 & 2 & 1 & 3 & 3 \\
\hline $\begin{array}{l}\text { Funds under } \\
\text { management }\end{array}$ & 1300m Euro & 100m Euro & $350 \mathrm{~m}$ Euro & 1200m Euro & 200m Euro & $280 \mathrm{~m}$ Euro \\
\hline $\begin{array}{l}\text { Number of portfolio } \\
\text { companies }\end{array}$ & 7 & 3 & 14 & 16 & 13 & 11 \\
\hline $\begin{array}{l}\text { Portfolio company } \\
\text { industries }\end{array}$ & $\begin{array}{l}\text { Consumer goods, } \\
\text { professional services, } \\
\text { manufacturing, petrol } \\
\text { distribution. }\end{array}$ & $\begin{array}{l}\text { Infrastructure, } \\
\text { automotive, industrial } \\
\text { products. }\end{array}$ & $\begin{array}{l}\text { Manufacturing, } \\
\text { professional services, } \\
\text { food and beverage, } \\
\text { pharmaceuticals, } \\
\text { industrial products. }\end{array}$ & $\begin{array}{l}\text { Consumer goods, } \\
\text { industrial products, } \\
\text { healthcare, } \\
\text { manufacturing, } \\
\text { maritime services, } \\
\text { environmental } \\
\text { services. }\end{array}$ & $\begin{array}{l}\text { Industrial products, } \\
\text { consumer goods, } \\
\text { automotive, } \\
\text { transportation, } \\
\text { energy, media. }\end{array}$ & $\begin{array}{l}\text { IT, industrial products } \\
\text { and services, } \\
\text { consumer goods, food } \\
\text { and beverage. }\end{array}$ \\
\hline \multicolumn{7}{|l|}{ Investment policy } \\
\hline Minimum investment & $40 \mathrm{~m}$ Euro & $\mathrm{n} / \mathrm{a}$ & $10 \mathrm{~m}$ Euro & $\mathrm{n} / \mathrm{a}$ & $5 \mathrm{~m}$ Euro & $10 \mathrm{~m}$ Euro \\
\hline Maximum investment & $125 \mathrm{~m}$ Euro & $\mathrm{n} / \mathrm{a}$ & $30 \mathrm{~m}$ Euro & $\mathrm{n} / \mathrm{a}$ & 20m Euro & $200 \mathrm{~m}$ Euro \\
\hline Target & $\begin{array}{l}\text { Medium size } \\
\text { companies operating in } \\
\text { Europe. Excludes } \\
\text { capital or industrial } \\
\text { goods sectors. }\end{array}$ & $\begin{array}{l}\text { Companies with a } \\
\text { turnover ranging from } \\
10 \text { to } 150 \text { million euros } \\
\text { in Northern and Central } \\
\text { Italy. Excludes real } \\
\text { estate and financial } \\
\text { service sectors. }\end{array}$ & $\begin{array}{l}\text { Companies valued } \\
\text { from } 15 \text { to } 100 \\
\text { million euros } \\
\text { operating in Europe } \\
\text { that have an } \\
\text { international market } \\
\text { focus. Excludes firms } \\
\text { in highly regulated, } \\
\text { labour-intensive or } \\
\text { commodity sectors. }\end{array}$ & $\begin{array}{l}\text { Companies operating } \\
\text { in Italy with a } \\
\text { turnover ranging from } \\
10 \text { to } 250 \text { million } \\
\text { euros. Excludes real } \\
\text { estate and financial } \\
\text { service sectors. }\end{array}$ & $\begin{array}{l}\text { Small to medium size } \\
\text { companies operating } \\
\text { in Italy. Focus on } \\
\text { firms seeking to } \\
\text { expand } \\
\text { internationally. }\end{array}$ & $\begin{array}{l}\text { Companies with a } \\
\text { turnover typically } \\
\text { ranging from } 40 \text { to } 50 \\
\text { million euros } \\
\text { operating in Northern } \\
\text { Italy. Excludes real } \\
\text { estate and financial } \\
\text { service sectors. }\end{array}$ \\
\hline Investment stage & Expansion, buyout & Expansion & Expansion, buyout & $\begin{array}{l}\text { Expansion, } \\
\text { replacement }\end{array}$ & $\begin{array}{l}\text { Expansion, } \\
\text { replacement, buyout }\end{array}$ & $\begin{array}{l}\text { Expansion, } \\
\text { replacement, buyout }\end{array}$ \\
\hline Ownership position & Majority & Mainly minority & Majority and minority & Mainly minority & Majority and minority & Majority and minority \\
\hline
\end{tabular}


Table 2

Control mechanisms implemented by PE firms to manage portfolio companies

\begin{tabular}{|c|c|c|c|}
\hline Contractual controls & Results controls & Behaviour controls & Social controls \\
\hline $\begin{array}{l}\text { Pre-contract } \\
\text { - } \quad \text { Letter of intent } \\
\text { - } \quad \text { Due diligence } \\
\text { Contractual clauses } \\
\text { - Investment amount and timing } \\
\text { - } \quad \text { Cash flow rights } \\
\text { - } \quad \text { Liquidilidution rights } \\
\text { - } \\
\text { Exit rights } \\
\text { Specification of, or right to } \\
\text { determine, exit route (e.g. trade } \\
\text { sell, IPO, secondary buyout) } \\
\text { Drag along rights (minority } \\
\text { shareholders required to sell) } \\
\text { Tag along rights (right to include } \\
\text { minority shareholding in any } \\
\text { majority shareholding sales) } \\
\text { Pre-emptive rights and right of } \\
\text { first refusal (right to purchase } \\
\text { shares of another owner before a } \\
\text { third party) } \\
\text { Buy-back / redemption rights } \\
\text { (right to sell shares back to initial } \\
\text { owner at a predetermined price } \\
\text { after a specified period of time) } \\
\text { Managerial selection rights } \\
\text { Replacement and selection of } \\
\text { managers } \\
\text { Veto rights } \\
\text { Right to veto specific managerial } \\
\text { decisions (e.g. extraordinary }\end{array}$ & $\begin{array}{l}\text { Reporting } \\
\text { - } \quad \text { Monthly reporting (key financial and } \\
\text { non-financial indicators) } \\
\text { Monthly or quarterly reporting of } \\
\text { detailed financial statements } \\
\text { - } \quad \text { Free cash flow projections } \\
\text { Tnnual audits } \\
\text { Target setting } \\
\text { - Strategic target setting with clear } \\
\text { time horizons } \\
\text { Budget target setting } \\
\text { Incentives } \\
\text { - Annual bonuses (e.g. cash payments, } \\
\text { share options) } \\
\text { Earn-out bonuses (incentives based } \\
\text { on performance of the firm over a } \\
\text { specified period, e.g. profit target } \\
\text { reached within a three year period) } \\
\text { Exit bonuses (based on e.g. internal } \\
\text { rate of return, investment multiple, } \\
\text { exit value) } \\
\text { Sweat equity (equity rights based on } \\
\text { non-monetary contributions of the } \\
\text { entrepreneur, i.e. time and effort) } \\
\text { Equity investment by entrepreneur or } \\
\text { executive managers (often 'pari } \\
\text { passu' with PE firm managers) }\end{array}$ & $\begin{array}{l}\text { Plans } \\
\text { - } \quad \text { Strategic business plan development } \\
\text { and reviews } \\
\text { - } \quad \text { Operational plan development and } \\
\text { reviews } \\
\text { Meetings } \\
\text { - } \quad \text { Shareholder meetings } \\
\text { - } \quad \text { Board of directors meetings } \\
\text { - } \quad \text { Management committees } \\
\text { - } \quad \text { Onsite visits } \\
\text { Rules and procedures } \\
\text { - } \quad \text { Strategic boundaries } \\
\text { - } \quad \text { Planning procedures and approvals }\end{array}$ & $\begin{array}{ll}\text { - } & \text { Partner selection } \\
\circ \quad \text { Reputation (e.g. personal } \\
\text { networks, investment banks, } \\
\text { local boutiques, CPAs) } \\
\quad \text { Relationship developed through } \\
\text { pre-contract interactions } \\
\text { - } \quad \text { Frequent and open dialogue } \\
\text { - } \quad \text { Reciprocal trust building } \\
\text { - Joint decision making } \\
\text { - Informal resolution of disagreements } \\
\text { - } \quad \text { Limited contractual breaches } \\
\end{array}$ \\
\hline
\end{tabular}




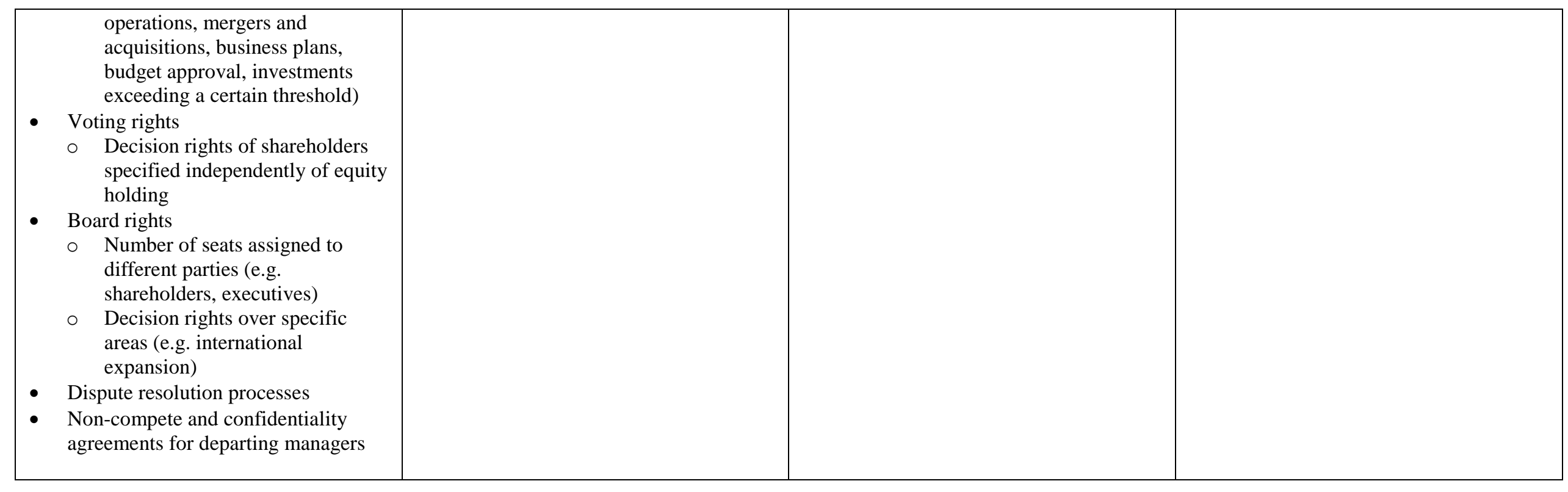




\section{Appendix A}

Interviews conducted

\begin{tabular}{llll}
\hline Firms & Interviewees & $\begin{array}{l}\text { Length } \\
\text { interviews }\end{array}$ & Transcription \\
\hline Consulting firm & Partner & 1 hour & Notes \\
& Senior manager & 1 hour & Notes \\
Firm 'M' & Investment manager & 2 hours & Transcribed \\
& Management team member & 2 hours & Notes \\
& CFO portfolio company M1 & 1 hour & Transcribed \\
Firm 'C' & Managing director A & 2 hours & Transcribed \\
& Managing director A & 2 hours & Transcribed \\
& Managing director A & 1 hour & Transcribed \\
Firm 'X' & Managing director A and investment manager B & 1 hour & Transcribed \\
& Managing director A and investment manager B & 1 hour & Transcribed \\
& CFO portfolio company X1 & 2 hours & Transcribed \\
& CFO and CEO portfolio company X2 & 2 hours & Transcribed \\
& Finance director portfolio company X3 & 2 hours & Transcribed \\
Firm 'F' & Senior partner & 2 hours & Transcribed \\
Firm 'A' & Managing partner & 2 hours & Transcribed \\
& Managing director & 2 hours & Transcribed \\
& Professional A, professional B, professional C & 1.5 hours & Transcribed \\
\hline
\end{tabular}




\section{Appendix B}

Interview check list

1. In which sector do you make investments? How did you identify the firms in which to make investments?

2. What kind of investments do you make (majority, minority, etc.)

3. What kind of strategies do you implement to create value with the portfolio companies?

4. Which resources and support are provided to the portfolio companies?

5. Which kind of agreement do you achieve before making the investment and which terms and conditions are regulated contractually?

6. Once the investment is made, which are the mechanisms employed to control and coordinate the activities of portfolio and what is their role:
a. Selection of key managers
b. Definition of intermediaries
c. Business planning
d. Reporting and performance measurement systems
e. Incentives
f. Communication and interaction mechanisms (frequency, subjects involved, modes)
g. Others

7. What are the key factors that explains the differences in the relationship with portfolio companies?

8. How do you define the exit strategy? 